\title{
Degradation of Brilliant Green by Using a bentonite Clay- Based Fe Nano Composite Film as a Heterogeneous Photo- Fenton Catalyst.
}

\author{
Khulood Abid Saleh AL-Saade * \\ Shatha Fadel Al-Saidi** \\ Hamdia Hateem Juad***
}

*Department of Chemistry, College of Science, University of Baghdad.

**Department of Chemistry, College of Science, University of Nahrain.

*** Department of Chemistry, College of Science for Women, University of Baghdad

E-mail: Khuloodabid@yahoo.com

Received 26/ 11/2014

Accepted 28/6/2015

(i) $\Theta \Theta$

This work is licensed under a Creative Commons Attribution-NonCommercial-

NoDerivatives 4.0 International Licens

\begin{abstract}
:
This paper aims to study the chemical degradation of Brilliant Green in water via photo-Fenton $\left(\mathrm{H}_{2} \mathrm{O}_{2} / \mathrm{Fe}^{2+} / \mathrm{UV}\right)$ and Fenton $\left(\mathrm{H}_{2} \mathrm{O}_{2} / \mathrm{Fe}^{2+}\right)$ reaction. $\mathrm{Fe}-\mathrm{B}$ nano particles are applied as incrustation in the inner wall surface of reactor. The data form X- Ray diffraction (XRD) analysis that $\mathrm{Fe}-\mathrm{B}$ nanocomposite catalyst consist mainly of $\mathrm{SiO}_{2}$ (quartz) and $\mathrm{Fe}_{2} \mathrm{O}_{3}$ (hematite) crystallites. B.G dye degradation is estimated to discover the catalytic action of Fe- B synthesized surface in the presence of UVC light and hydrogen peroxide. B.G dye solution with $10 \mathrm{ppm}$ primary concentration is reduced by $99.9 \%$ under the later parameter $2 \mathrm{ml} \mathrm{H}_{2} \mathrm{O}_{2}, \mathrm{pH}=7$, temperature $=25^{\circ} \mathrm{C}$ within $10 \mathrm{~min}$. It is clear that $\mathrm{pH}$ of the solution affects the photo- catalytic degradation of B.G dye. All the conditions above have been studied to reach the optimum operation condition for the two processes Fenton and photo- Fenton. The B.G degradation process follows first- order reaction rules. Photo- Fenton process causes a more efficient oxidation rate than the Fenton process. So, the photo- Fenton degradation is an effective and economic process by producing higher percentage of degradation and mineralization in short radiation time.
\end{abstract}

Key words: Advanced Oxidation Processes, Fenton, Photo-Fenton, B.G dye.

\section{Introduction:}

All dyes molecules are stable and difficult to degrade biologically [1], so they lead to pollution problems like a form of colored waste water discharged; into environmental water bodies [2]. The adsorption procedure is the most efficient method for removing the pollutant dyes form waste water [3-5].
The dye will be transferred to solid phase thereby keeping the effluent volume to a minimum [6-8]. Also the adsorbent can be used more than one time by being regenerated and stored in a dry place [4-8]. The brilliant green dye as used in this study is triphenyl nitrogen containing cationic dye. The 
exact structure of the brilliant green dye is given in Figure (1). Brilliant green is chemically described as ammonium, 4(diethylamino)-alphaphenylbenzylidene) $\left(\mathrm{C}_{27} \mathrm{H}_{34} \mathrm{~N}_{2} \mathrm{O}_{4} \mathrm{~S}\right)$ with $\lambda_{\max }=625 \mathrm{~nm}$ and molecular weight 482 g. $\mathrm{mol}^{-1}$. The use of brilliant green (B.G) dye has been banned in many countries due to its carcinogenic nature [1].It is used as a dye to color synthetic fibers and silk biological stain, dermatological agent, veterinary medicine, and as an additive to poultry feed to inhibit propagation of mold, intestinal parasites and fungus.It is also extensively used in textile dying and paper printing. It is considered highly toxic for humans and animals because it can cause permanent injury to eyes. It also causes irritation to the respiratory tract that leads to cough and shortness of breath. It can cause irritation to the gastrointestinal tract, which also results in nausea, vomiting and diarrhea in human beings [9].

$$
\mathrm{Fe}^{2+}+\mathrm{H}_{2} \mathrm{O}_{2} \stackrel{\mathrm{UV}}{\longrightarrow} \mathrm{Fe}^{3+}+\mathrm{OH}+\mathrm{OH}^{-}
$$

\section{Materials and Methods:}

\section{Materials:}

Birilliant green (B.G) as used in this study is obtained from Merck com. On the other hand, $\mathrm{H}_{2} \mathrm{O}_{2} \quad(30 \%), \quad \mathrm{Fe}$ $\left(\mathrm{NO}_{3}\right)_{2} .9 \mathrm{H}_{2} \mathrm{O}, \mathrm{H}_{2} \mathrm{SO}_{4}, \mathrm{NaOH}, \mathrm{Na}_{2} \mathrm{CO}_{3}$ and $\mathrm{HCl}(37 \%)$ are obtained from Sigma com. All predation is achieved using double distilled water. The bentonite clay used in present study is supplied from Geological Survey in Ministry of Industrial mineral, Baghdad, Iraq.

\section{Preparation of Catalyst:}

The preparation of $\mathrm{Fe}$ - bentonite nanocomposite flows in the following steps: an aqueous dispersion of bentonite clay is prepared by adding $10 \mathrm{~g}$ bentonite clay to $500 \mathrm{~mL} \mathrm{H}_{2} \mathrm{O}$ under vigorous stirring for $3 \mathrm{hs}$ at $25^{\circ} \mathrm{C}$. Sodium carbonate is added slowly as a powder into a vigorously stirred $0.2 \mathrm{M}$<smiles>CCN(CC)c1ccc(C(=C2C=CC(=[N+](CC)CC)C=C2)c2ccccc2)cc1</smiles>

Fig. (1): Structure of Brilliant Green

(AOP's) have been developed during the past ten years and various kinds of advanced oxidation processes (AOP's) are used to remove organic pollutants from waste water. Principled (AOP's) are based on the generation of $\mathrm{OH}$ radicals in the solution. These $\mathrm{OH}$ radicals then will be responsible for the oxidation of organic compounds and act with non-selectivity. The photo reaction will cause the formation of $\mathrm{OH}$ radicals and regeneration of $\mathrm{Fe}^{2+}$ which can be expressed as follows [10]:

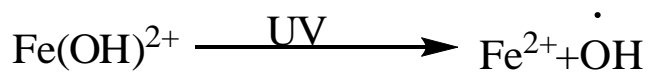

solution of iron nitrate for $3 \mathrm{~h}$ such that a molar ratio of $1: 1$ for $\left[\mathrm{Na}^{+}\right] /\left[\mathrm{Fe}^{3+}\right]$ is established. $500 \mathrm{~mL}$ solution from the second step is added drop by drop into the dispersion of bentonite clay prepared in the first step under vigorous stirring. The suspension is stirred for $3 \mathrm{hs}$ followed by ageing at $100^{\circ} \mathrm{C}$ in an autoclave for $48 \mathrm{~h}$ and finally $1000 \mathrm{~mL}$ solution containing Fe-B nanocomposite is obtained for the coating of the Fe-B nanocomposite on the stainless steel plate substrate. The coating of $\mathrm{Fe}-\mathrm{B}$ nanocomposite on the inner wall surface of photo- reactor is conducted by thermal spray method [11]. The photoreactor is made of stainless steel pipe with diameter of $4 \mathrm{~cm}$ and length $15 \mathrm{~cm}$, as shown in Figure (2). 


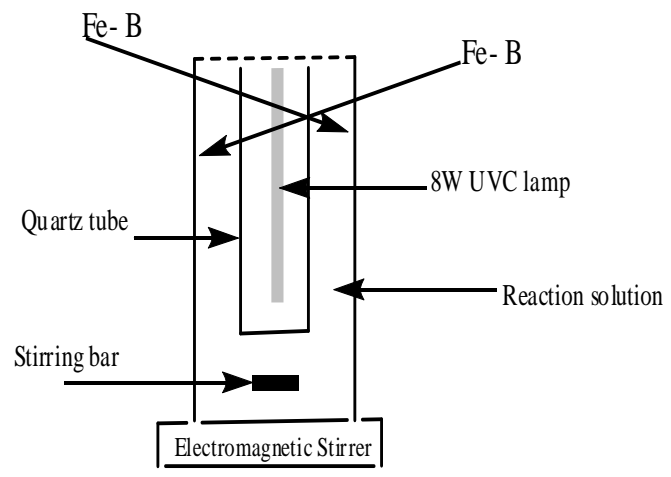

Fig. (2): Experimental Set- up of the Photo- Reactor Coated with A Fe- B [12].

\section{Preparation of Dye Sample:}

Standard stock solutions of $500 \mathrm{mg} / \mathrm{L}$ of brilliant green are prepared by diluting the corresponding mass of brilliant green in de- ionized water and protected from light. A different initial concentration of brilliant green is prepared by further diluting the standard stock solutions.

\section{Results and Discussion:}

1. Characterization of the

\section{Catalyst:}

\subsection{XRD:}

(SHIMADZU 6000 X-Ray) X- ray diffraction is used to analyze Fe- B nanocomposite, and the result is shown in Figure (3). The strong diffraction peaks at $2 \Theta$ of $\left(25.5^{\circ}, 26.2^{\circ}\right)$ indicate that the Fe-B nanocomposite mainly consists of $\mathrm{SiO}_{2}$ (quartz) and $\left(33.15^{\circ}\right.$, 39.28 ${ }^{\circ} \mathrm{Fe}_{2} \mathrm{O}_{3}$ (hematite).The increasing in particle size lead, to higher intensity of diffraction pattern[13].

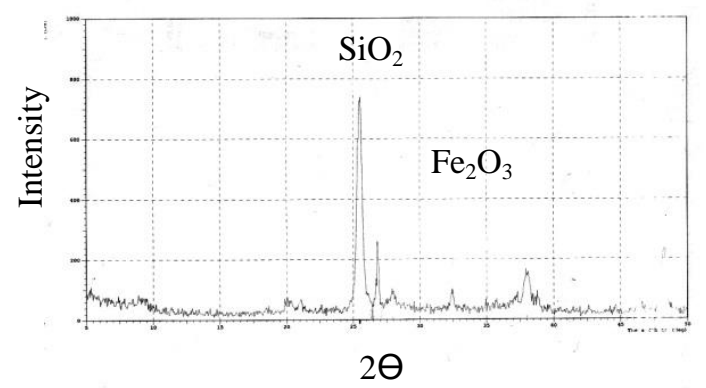

Fig. (3): XRD for: Fe-B nanocomposite

\subsection{AFM Analysis:}

Atomic force microscope (AFM, AA3000 of Angstrom Advanced Inc. USA), is used to investigate $\mathrm{Fe}-\mathrm{B}$ nanoparticles.

AFM analysis represents data in three dimensions, so that it is possible to measure the height of the nanoparticles quantitatively. Figure (4) explain the particle size is less than $100 \mathrm{~nm}$ and show the morphology of nanoparticle and the average particle size of $\mathrm{Fe}-\mathrm{B}$ nanocomposite is around $80 \mathrm{~nm}$.
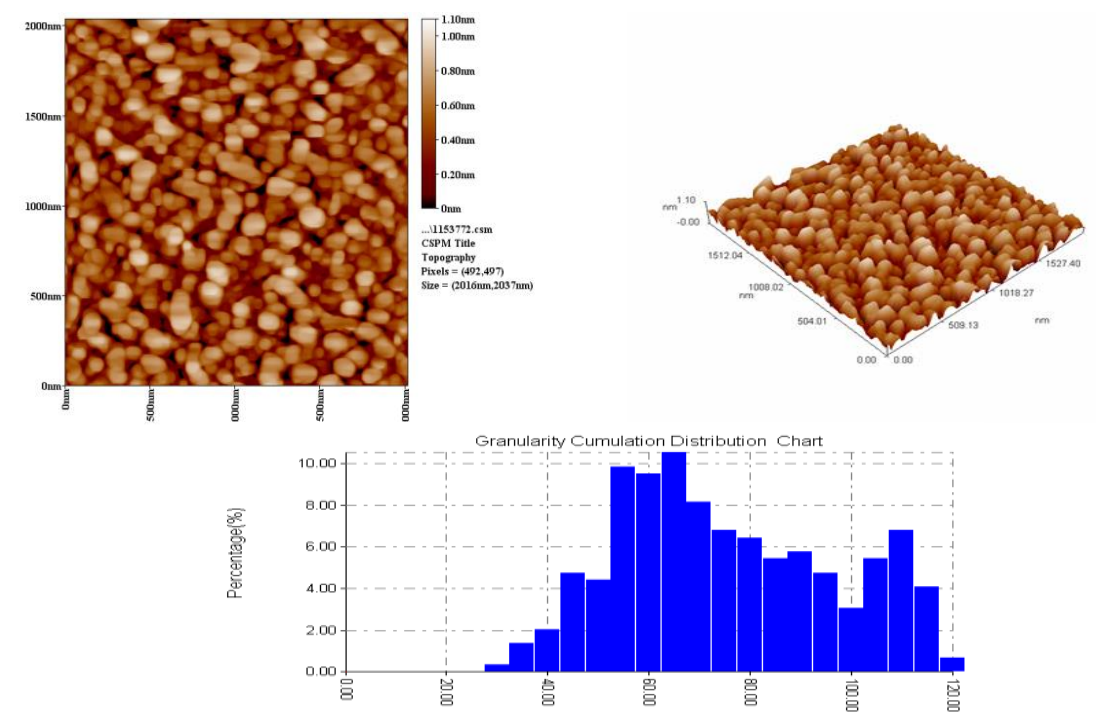

Fig. (4): AFM of Fe- Bentonit Nano composite 


\section{2- Degradation of Brilliant Green:}

Figure (5) shows the calibration curve for B.G which is determined in $\lambda \max _{\max }=$ $624 \mathrm{~nm}$ that obeys the (Lambert beer's law) at specific concentrations prepared for each compound. After that, the absorption has been recorded and a calibration curve is plotted between adsorption and concentration, the best line between the points has been drawn.

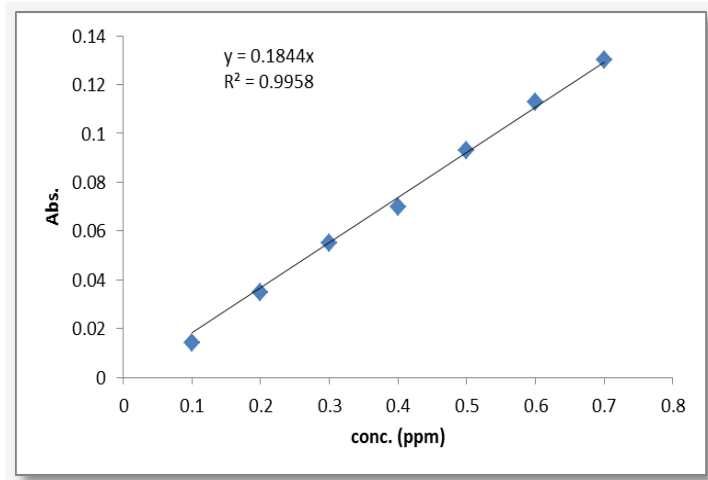

Fig. (5): Calibration Curve of B.G at $\lambda$ $\max =624 \mathrm{~nm}$

To study the discoloration of B.G dye, the UV-visible absorption spectra of (10 ppm) B.G dye solution at a $\mathrm{pH}=7.0$ before and after treatment with photoFenton catalyst in the presence of $8 \mathrm{~W}$ UVC are measured and presented in Figure 6.

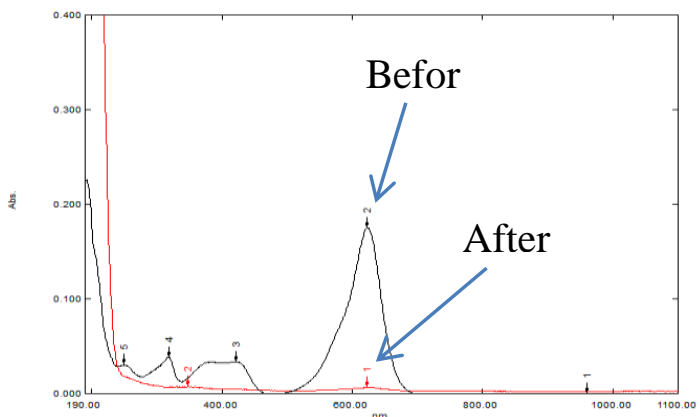

Fig. (6): UV-Visible Spectra of The 10 ppm of B.G Solution Before and After Treatment with Photo- Fenton Catalyst At $\mathrm{pH}=7.0$ and 298.15K For $20 \mathrm{~min}$.

To study the effect of initial dye concentration on the degradation efficiency, the experiments are carried out by using different initial concentration $(10-100) \quad \mathrm{ppm}$ at temperature $298.15 \mathrm{~K}, \mathrm{pH}=7$, and in presence $\left(2 * 10^{-4} \mathrm{M} \mathrm{H}_{2} \mathrm{O}_{2}+\right.$ catalyst+ $8 \mathrm{~W}$ UVA), Figure7 shows that the higher the initial dye concentration after 20 min leads to $90 \%$ percentage, while for 10ppm B.G concentration after 20 min reaches to $99.9 \%$. This phenomenon might be due to the fact that the number of dye molecules is increased but the number of $\mathrm{OH}$ is still constant. On the other hand, with the increase in initial concentration of the dye, more dye molecules are adsorbed onto the surface of the catalyst, leading to a decrease in oxidation process. Figure (8) shows dark- Fenton without any UV light, in presence of $\left(2 * 10^{-4} \mathrm{M} \mathrm{H}_{2} \mathrm{O}_{2}\right)$, and the catalyst at temperature $298.15 \mathrm{~K}, \mathrm{pH}=$ 7, the degradation of $10 \mathrm{ppm} \mathrm{B.G} \mathrm{dye}$ after $20 \mathrm{~min}$ is $99 \%$ and for 100ppm dye is $90 \%$. Similar results are obtained with photo- Fenton reaction. Figure (9) shows that in the absence of $\mathrm{H}_{2} \mathrm{O}_{2}$, with the catalyst at temperature of $298.15 \mathrm{~K}$, $\mathrm{pH}=7$, the degradation of $10 \mathrm{ppm} \mathrm{B.G}$ dye after $20 \mathrm{~min}$ is $95 \%$ and for $100 \mathrm{ppm}$ dye is $91 \%$. This is indicates that $\mathrm{H}_{2} \mathrm{O}_{2}$ is important in diluting concentration of dye but isn't important in high B.G concentration. Figure (10) shows the effect of $\mathrm{H}_{2} \mathrm{O}_{2}$ concentration on the B.G dye degradation at temperature $298.15 \mathrm{~K}, \mathrm{pH}=7$, and (catalyst+ $8 \mathrm{~W}$ UVA), $10 \mathrm{ppm}$ of B.G dye degradation is $99 \%$ in case the concentration of $\mathrm{H}_{2} \mathrm{O}_{2}$ is $0.4 * 10^{-3} \mathrm{M}$ while the degradation percentage is $99.9 \%$ in case of using $3 * 10^{-3} \mathrm{M} \quad \mathrm{H}_{2} \mathrm{O}_{2}$ for high B.G dye concentration (100ppm). Low $\mathrm{H}_{2} \mathrm{O}_{2}$ concentration $\left(0.4 * 10^{-4} \mathrm{M}\right)$ leads to making the degradation percentage reach $89 \%$.It is clear that $0.8 * 10^{-3} \mathrm{M}$ $\mathrm{H}_{2} \mathrm{O}_{2}$ is suitable to reach degradation percentage ranging (99-100)\% for B.G concentration 10,60,100ppm. Figure (11) shows the effect of $\mathrm{pH}$ on percentage degradation of B.G dye at temperature $298.15 \mathrm{~K}$, and in presence of $\left(2 * 10^{-4} \quad \mathrm{M} \mathrm{H}_{2} \mathrm{O}_{2}+\right.$ catalyst $8 \mathrm{~W}$ 
UVA).It is clear that the photo- Fenton degradation depends strongly on $\mathrm{pH}$ of the reaction medium, whereas the degradation percentage of B.G increases with increasing $\mathrm{pH}$ up to 7.0 and then percentage degradation of B.G decreases with increasing $\mathrm{pH}$ to $\mathrm{pH}=14$. The effect of temperature on the degradation of B.G dye is investigated in three different temperatures $(298.15,308.15$, 318.15) $\mathrm{K}$ at the following condition $\mathrm{pH}=7$, with different initial concentration $(10,20,30,40,60,80$, 100) ppm of B.G. The results in Figure (12) show that, the degradation 10ppm of B.G decreases as temperature increases indicating an anti- Arrhenius relation. Then after increasing the temperature more than $318.15 \mathrm{~K}$, the $\mathrm{R} \%$ stays with in the same level. Removal percentage for $(20,30,40,60,80,100)$ ppm increases when temperature increases until $320 \mathrm{~K}$ the $\mathrm{R} \%$ does not change for 320 to $330 \mathrm{~K}$. The degradation of B.G dye by Fenton is a first order reaction. This is determined from the slope of the linear plot of logarithmic remaining B.G concentration versus treatment time $t$ as shown in the following Figure (13).

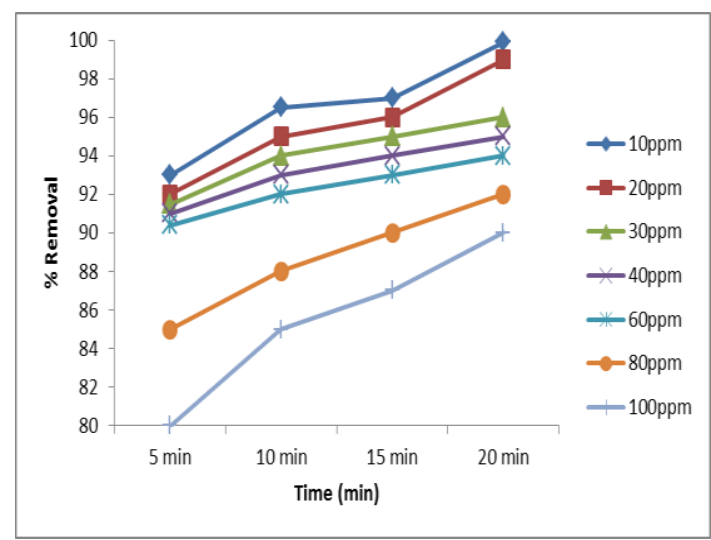

Fig.(7): Effect of Initial Dye

Concentration on Degradation of B.G dye; at Temperature $298.15 \mathrm{~K}, \mathrm{pH}=7$, and $\left(2 * 10^{-4} \mathrm{M} \mathrm{H}_{2} \mathrm{O}_{2}+\right.$ Catalyst $+8 \mathrm{~W}$ UVA).

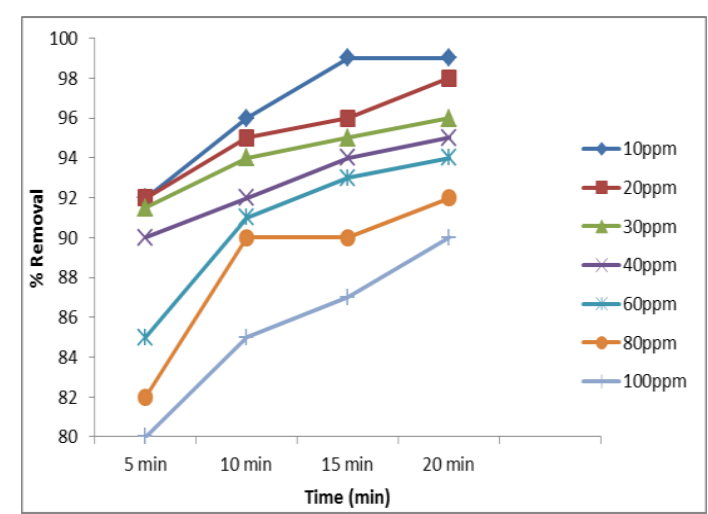

Fig. (8): \% R Against Time for Different B.G dye Concentration with $2 * 10^{-4} \quad \mathrm{H}_{2} \mathrm{O}_{2}$ and without UV- light at $\mathbf{2 9 8 . 1 5}$

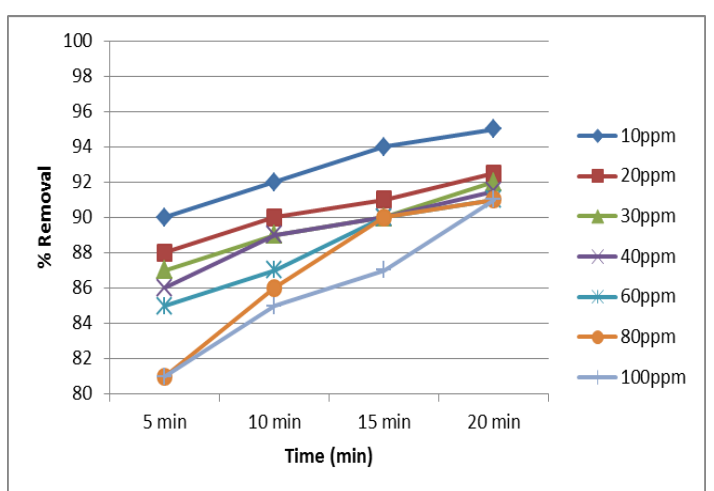

Fig. (9): \% R Against Time for Different B.G Dye Concentration with UV- Light and without $\mathrm{H}_{2} \mathrm{O}_{2}$ at 298.15

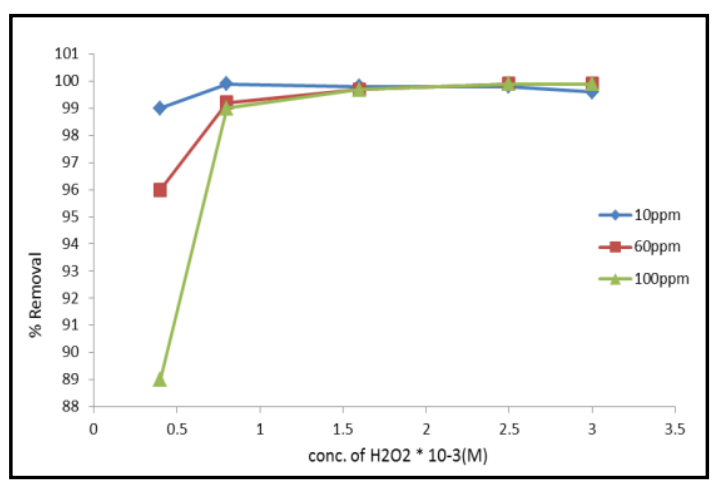

Fig. (10): Variation of $\mathrm{R} \%$ with $\mathrm{H}_{2} \mathrm{O}_{2}$ Concentration for Different B.G Concentration in Presence of UV- Light and Catalyst at $298.15 \mathrm{~K}$ and $\mathrm{pH}=7$ 


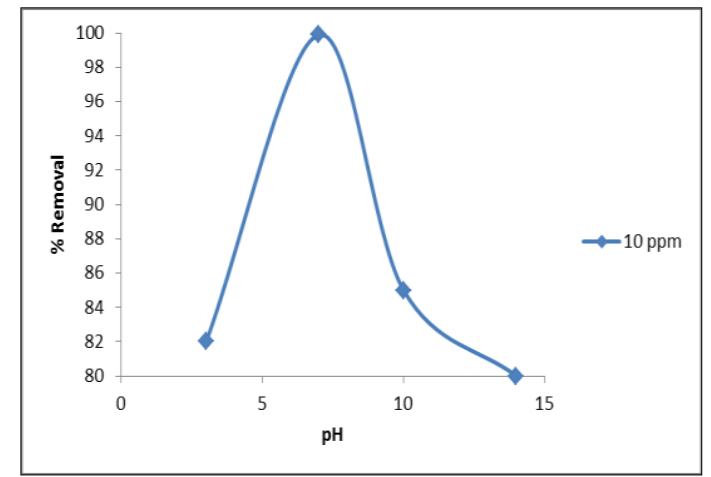

Fig. (11): pH Value and The \% Removal

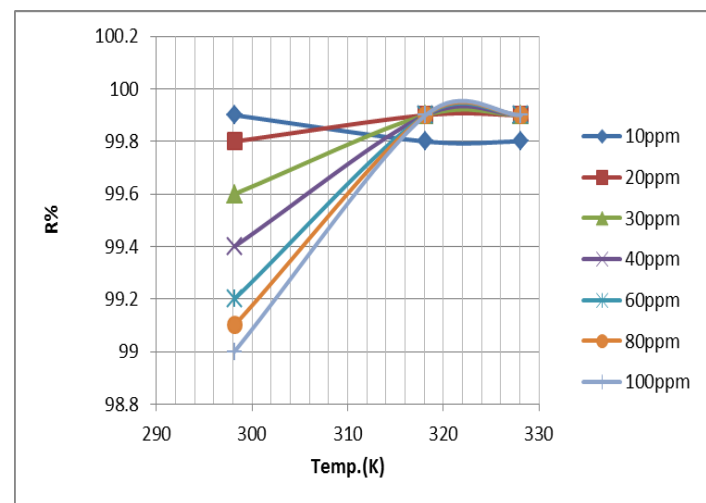

Fig.(12): \% $\mathrm{R}$ against Temperature for Different B.G Dye Concentration after 20 Minutes

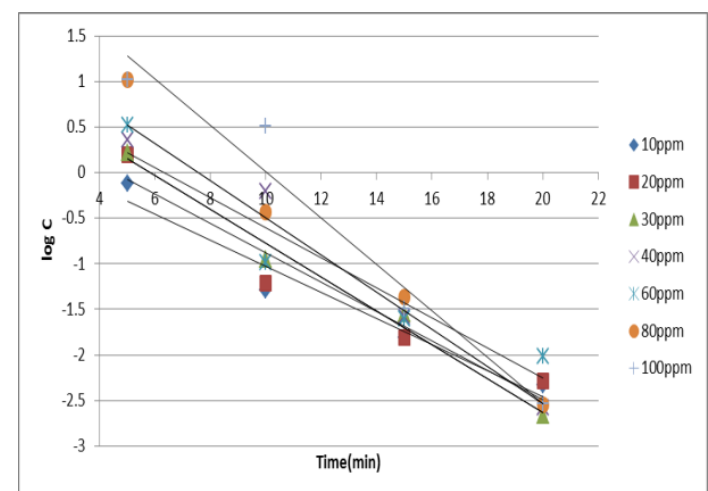

Fig. (13): The Relation between $-\log C$ and Time (min) at Temperature 298.15K

\section{Conclusion:}

Degradation of B.G dye is conducted by using bentonite clay- based $\mathrm{Fe}$ nanocomposite (Fe-B) film as a heterogeneous photo-Fenton catalyst in the presence of UVC light and $\mathrm{H}_{2} \mathrm{O}_{2}$. Under optimal conditions $\left(\mathrm{pH}=7,2^{*} 10^{-}\right.$ ${ }^{3} \mathrm{M} \mathrm{H}_{2} \mathrm{O}_{2}$, and $1 * 8 \mathrm{~W}$ UVC), $99.9 \%$ degradation of B.G dye can be achieved in 20 minute. The Fe-B coated catalyst film could be used in the pretreatment of wastewater for an integrated system consisting of a photochemical reactor and biological reactor.

\section{Reference:}

[1] Wang, S. and Li, H. T. 2007. Kinetic Modeling and Mechanism of Dye Adsorption on Unburned Carbon. Dyes Pigm, 72(2):308-314.

[2] Royer, B. ;Cardoso, N. F.; Lima, E. C.; Vaghetti, J. C. P.; Simon, N. M.; Calvete, T. and Veses, R. C. 2009. Applications of Brazilian-Pine Fruit Shell in Natural and Carbonized Forms as Adsorbents to Removal of Methylene Blue from Aqueous Solutions - Kinetic and Equilibrium Study. J. Hazard. Mater, 164(1): 1213-1222.

[3] Pavan, F. A. S.; Dias, L. P. and Lima, E. C. 2008. Benvenutti, Removal of Congo red from Aqueous Solution by Aniline propyl silica Xerogel. Dyes Pigm, 76(1): 64-69.

[4] Royer, B.; Lima, E. C.; Cardoso, N. F.; Calvete, T. and Bruns, R. E. 2010. Statistical Design of Experiments for Optimization of Batch Adsorption Conditions for Removal of Reactive Red 194 Textile Dye from Aqueous Effluents. Chem. Eng. Commun, 197(2): 775-790.

[5] Gupta, V. K. and Suhas, I. A. 2009. Application of Low-cost Adsorbents for Dye Removal - A Review. J. Environ. Manage, 90(1): 2313-2342.

[6] Pavan, F. A.; Gushikem, Y.; Mazzocato, A. S.; Dias, S. L. P. and Lima, E. C. 2007. Statistical Design of Experiments as a Tool for Optimizing the Batch Conditions to Methylene Blue Bio sorption on Yellow Passion Fruit and Mandarin Peels. Dyes Pigm, 72(2): 256-266.

[7] Wang, S. and Zhu, Z. H. 2007. Effects of Acidic Treatment of Activated Carbons on Dye Adsorption. Dyes Pigm, 75(2): 306314.

[8] Royer, B.; Cardoso, N. F. and Lima, E. C. 2009. Organo functionalized Kenyaite for Dye Removal from 
Aqueous Solution, J. Colloid Interface Sci., 336 (1): 398-405.

[9] Tatiana, C.; Eder, C.; Lima, N. F.; Cardoso, S. L. P. and Emerson S. 2010. Removal of Brilliant Green Dye from Aqueous Solutions Using Home Made Activated Carbons. CLEAN - Soil, Air and Water, 38 (5): 521-532.

[10] Bossmann, S. H.; Oliveros, E.; Gob, S.; Kantor, M.; Goppert, A.; Lei, Y. P. L. and Braun, A.M. 2001. Degradation of polyvinyl alcohol (PVA) by homogeneous and heterogeneous photo catalysis applied to the photochemical enhanced Fenton reaction. Water Sci. Technol., 44 (5): 257-262.

[11] Mihir, K. S. 2011. Degradation and mineralization, of organic contaminants by Fenton and photoFenton processes: review of mechanisms and effects of organic and inorganic additives. Research $\mathrm{J}$. of Chem. and Environment, 15 (2): 96-112.

[12] Devi, L. G. and Raju, K. S. A. 2009. Degradation mechanism of diazo dyes by photo-Fenton-like process: Influence of various reaction parameters on the degradation kinetics. Bulgarian Chemical Communications, 15 (1): 385-390.

[13] Mohamed, E. M.; Ali, T. A. and Mohamed, I. 2013. Heterogeneous Fenton process using steel industry wastes for methyl orange degradation. Apply Water Sci., 3 (1): 263-270.

\section{دراسة حركية للتفكثك الضوئي نوع (فنتون) المحفز لصبغة Brilliant Green

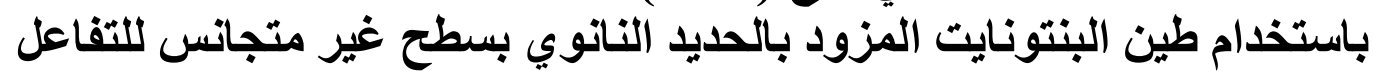 الضوئي المحفز}

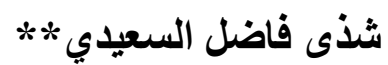

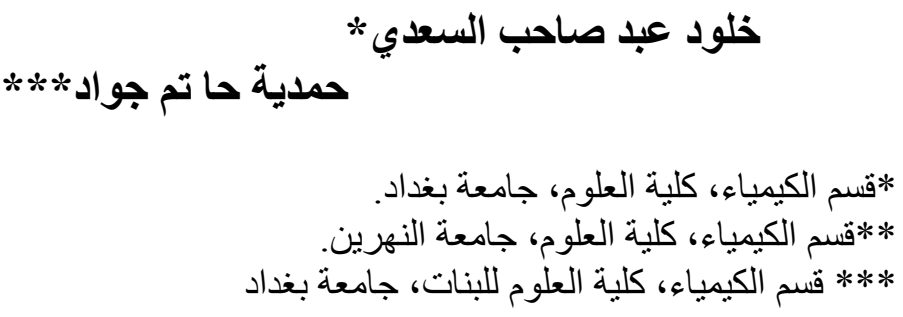

بهدف هذا البحث الى در اسة التفكلك الضوئي لصنغة (B.G.) Brilliant Green بالماء باستخدام تفاعل فينتون الضوئي $)$ (Fe

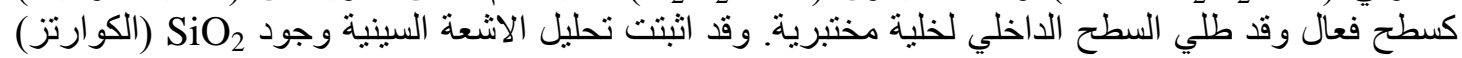
بصورة رئيسية ووجود الحديد النانوي بهيئة

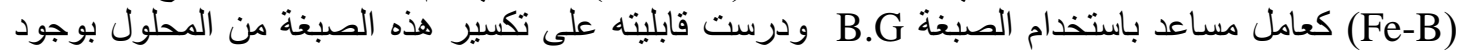

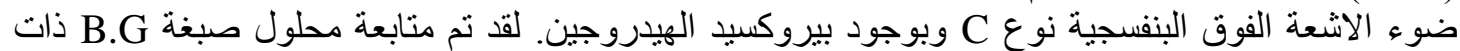

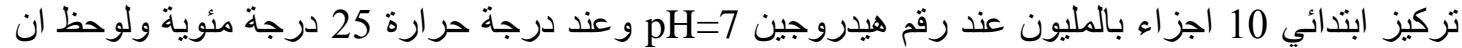

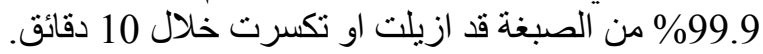
ان للرقم الهيدروجيني pH تأثير كبير في التكسير الضونئي المحفز لصبغة B.6 كما تبين من خلال هذه الدراسة.

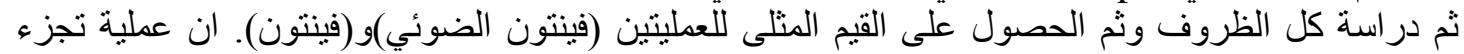

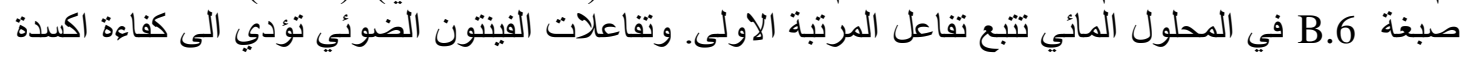

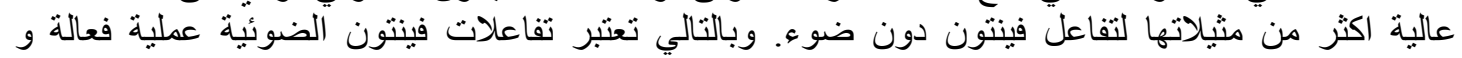

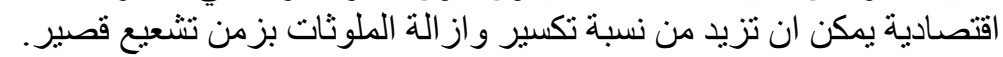
الكلمات المفتاحية : عمليات الأكسدة المتقدمة ، فنتون ، فنتون الضوئي ، صبغة برلنت الخضراء. 